\title{
Compliance Analysis of the Best Practices of Corporate Governance in Morcco: Case of the Large Market Capitalization Companies
}

\author{
Zoubida Samlal, Rachid Jahidi
}

Université Hassan I, ENCG de Settat, Morocco

\begin{abstract}
Amid the leading position of Morocco in terms of Corporate Governance compared to peer countries from the Middle East and Africa (MEA) region, a number of legislative and operational limitations still as of today impede the process of implementation of these practices [1].

This leads us to question the extent to which the large market capitalization firms have implemented these practices. Therefore, the present article aims to present the findings of a semi-directive qualitative research conducted on the 20 largest capitalizations of Casablanca Stock Exchange.

We will attempt to contextualize the most widely used Corporate Governance scoring system (Institute of Shareholders Services)to the Moroccan context.

We will, then, analyze the state of progress of the selected equity listed companies in terms best practices of corporate governance by comparing our findings dated as of 2017 with the last report of the Moroccan Institute of Directors (IMA) of 2012.
\end{abstract}

Keywords-Corporate Governance, RM/ISS, Semidirective qualitative research, and Moroccan equity Listed Companies.

\section{INTRODUCTION}

Morocco, the 3rd largest financial market and the 2nd most promising emerging economy in Africa, has underway from early 1990's a series of economic and regulatory reforms which has fostered, in 2008, to the establishment of the national code of corporate governance [2].

According to the ROSC report [3], the national code of corporate governance in Morocco complies with the Organization for Economic Co-operation and Development (OECD) principles in terms of shareholder rights, disclosure and the role of board of directors. This report acknowledges the initiatives of policy makers to update and modernize the legal and regulatory frameworks as well as to strengthen the enforcement structures such as the Moroccan Capital Markets Authority (AMMC) and the central bank (Bank AlMaghrib- - BAM).
In 2012,the AutoritéMarocaine des Marchés de Capitaux (AMMC), the Moroccan Secutities Exchange Commission, has mandated the Moroccan Institute of Administrators (IMA) toconduct a survey regarding the application of best practices of corporate governance within publicly traded companies. This market survey is intended to be re-conducted every three years. However, the last report issued by this organization was as of 2012 [4]. Thus, it seems interesting to investigate the state of play of best practices of corporate governance in the publically traded companies since the last report of IMA in 2012[4].

Consequently, our work attempts to answer the following questions:

1. To which extent the international norms and more specifically the recommendations of Institutional Shareholders' Services (ISS) are applicable to the Moroccan large market capitalizations? and,

2. Did these companies improve their best practices since the last report of IMA in 2012?

To this purpose, our article will be organized in three parts. The first part will tackle the literature on the best practices of corporate governance. The second part will present our exploratory qualitative study in terms methodology. The last part will gauge the compliance to the international norms (ISS) as well as the state of progress of corporate governance within the large equity listed companies.

\section{LITERATURE REVIEW}

The main objective of corporate governance is to 'govern' the behavior of managers and align their decisions to the best interests of shareholders. Thus, the act of 'governess' underpins two functions: a "constraining" function which is represented by the disciplinary paradigm of corporate governance and an "enabling" educational function covered by the cognitive approach of governance[5].

According to VO and Phan[6], the literature review from relevant academic studies has indicated several common characteristics relative to corporate governance such as: 1-board effectiveness; 2-the independence of audit 
committee; 3-board compensation; and4-shareholder's protection.

\section{A. Board effectiveness}

Emerged from the contractual theories of corporate governance, the board effectiveness depends on how well this latter performs its monitoring and strategic advisory roles [7] and [8]. These authors state that firms with audit committees and remuneration committees are related to higher performance.

Chen et al. [9] argued that board characteristics such as composition and internal functioning are crucial to conceptualizing and determining board effectiveness based on the shareholder perspective.

\section{B. Audit committee}

A number of studies have found that companies with an audit committee, particularly when the committee is active and independent, have less chance for the occurrence of fraud and other irregularities in reporting [8].The recommendations of these researchersconsent on the importance of the independence and competence of the audit committee members.

Moreover, Love [10] states that the audit committee should be permanent, independent, reporting directly to the board and having an advisory function with at least one member been independent and having expertise in accounting and/or auditing.

\section{Shareholders' protection provisions}

Since shareholders exercise their power by voting for directors and on major corporate issues, experts focus on voting procedures in evaluating shareholder rights [11].

These rights, which refer to anti-director rights, measure how strongly the legal system favors minority shareholders against managers or dominant shareholders in the corporate decision making process, including the voting process namely: voting by correspondence, cumulative voting, right to challenge director's decisions in courts, preemptive right to buy new issues of stock, and the share capital needed to call an extraordinary shareholders' meeting [11].

\section{Compensation of executives}

According to Affes [12], the fundamental dilemma of corporate governance is the imperfect alignment of incentives between shareholders and managers, which can lead to behaviors and decisions by managers that are not in the interests of the firm's shareholders. This author refers to the pioneer work of Jensen and Meckling in 1976 and states that when managers act in their own personal interest at the expense of shareholders, it results in agency costs for the firm's owners, which reduces value of shareholders. Several authors [11] [12] [13] explainthat shareholders can use managerial incentives to help align the manager's interests with those of shareholders.

\section{METHODOLOGY}

\section{A. Data collection}

Our study was carried out over a five months period (from October 2016 to February2017)in whichwe used as a primary method of data collection the interviewing techniques.

Along with it, andto a limited extent, we also usedofficial market reports as a complementary source of information. An interview guide was elaborated to facilitate the process of data collection. The choice and development of semi-structured questions were justified and been based upon the literature review and the main recommendations of the ISS scoring metric.

Most of interviews were mediated by telephone (12 out 20) while the remaining were conducted face to face.

Due to the sensitivity of the subject, no verbatim audios were allowed and all the data were collected from transcripts taken during the telephone/ face to face interviews.

Our points of contact were the chief financial officers (CFO), control directors and the senior management of the selected companies.

The selection of our sample of companies was purposive and criteria based. We selected 20 equity listed companies. Our selection was based on two criteria:largecap companies incorporating the FTSE CSE Morocco15 index, and / or belonging to major international groups.

Five sectors were represented in this study namely: financial sector (8 enterprises), real estate and construction (4 enterprises), energy and mining (2 enterprises), telecommunication and new technologies (2 enterprises) and retail and consumer products (4 enterprises).

The choice of equity listed companies was justified by the lenience of these latter to adopt and comply with the best practices of corporate governance, more stringent market regulations, and the availability of financial and corporate information.

\section{B. Data analysis}

Data analysis was based on a thematic conceptual framework developed as a part of our doctoral project.

Data were analyzed using an iterative approach whereby transcripts were coded according to a thematic framework, allowing mechanisms and practices of corporate governance to emerge in our analysis in line with our literature review.

Transcripts were analyzed using NVIVO software. Content analysis was predominantly used and in a lesser extent textual analysis was applied. 
We also used a comparative analysis when assessing the degree of progress of the best practices of corporate governance in Moroccan large capitalizations between the periods of 2012 (report of IMA) and 2017 (findings of our study).

\section{FINDINGS}

As reported earlier, we will underway two analyses. For the compliance analysis, we have chosen as an international reference the Corporate Governance Quotient (CGQ) which is the rating metric under the flagship of the Institute of Shareholder Services (ISS). As per the evolution analysis, we have chosen the ten criterions highlighted in the IMA report [4].

\section{A. Compliance to the international norms (ISS standards)}

The CGQ scoring system classified the best practices of corporate governance in seven requirements namely: 1board composition, 2- specialized committees, 3shareholders' protection provisions, 4- mandates policy, 5- progressive practices, 6- audit committee and 7compensation of directors.

\section{Board composition}

The independence and size of board of directors for Moroccan large capitalizations are merely in line with the recommendations of the ISS scoring metric.

Interestingly,though the Article 39 of Law 17-95 on the joint stock companies along with the national code of corporate governancerequire the independence criteria but they do not impose the majority quota. Understandably, the independence requirements are not fully met due to the overriding requirements the acting national code of corporate governance in Morocco.

\section{Specialized committees}

Only one third of our targeted companies have a specialized committee (e.g. the governance and nomination committee.) The remainder confirms that this function is carried out by the board of directors.

The independence requirement as it is stated by the ISS metric is not met by any of the panel interviewed. More importantly, the joint stock act and the national code of corporate governance do not require independence of such committee.

\section{Shareholders'protection provisions}

The results of our study have shown that our entire sample of companies complies with these provisions except the postal voting which is not a market practice in Morocco.
According to our respondents, the provisions of ISS converge with the Law 17-95 on the joint stock companies and the AMMC act related to the legal provisions of publically listed companies [15].

\section{Mandates policy}

Half of our panel confirms that their CEOs sit on other boards while no former CEO serves as a board member. On average, the CEO and senior management serve one to two other mandates on behalf of their respective companies which are in line with the ISS standards (CEOs must not sit in more than 5 other boards.)

Interestingly, our respondents confirm to not control if their CEOs exercise other external/third party mandates. It is to mention also that the acting code as well as the joint stock act do not provision for the limit number of mandates of CEOs and senior management.

\section{Progressive practices}

The findings of our study point out a substantial divergence between the market practices and the ISS recommendations. The quasi majority of our panel does not comply with all of these norms.

\section{Audit committee}

As per the independence requirement, more than half of our panel(14 enterprises out of 20) confirms havinga distinct audit committee.Furthermore, the audit committee accounts on average half of its members as independent while the remaining members are the chief financial officers and the control directors.

The lack of compliance in terms the independence criteria is justified by the provisions of Law 17-95 on the joint stock companies which require that the chief financial officer as well as the control director to be part of the audit committee[14].

The transparency of auditor policy is not met by any of our sample of enterprises. According to our respondents, this discrepancy is attributed to the fact that the acting regulatory framework does not require such practice [15].

\section{Compensation of directors}

Though our panel is not fully compliant, more than half of our sample (13 enterprises out of 20) hasalready put in place a stock option plan for their executives. According to our respondents, the stock option provision is optional and only applied in the financial sector companies affiliated to international groups.

The approval of executive compensation by shareholders is been met by all our panel of interviewees in line with the provision of the Law 17-95 on the joint stock companies [14]. 
The disclosure of the compensation of executives is not applied by any of our interviewed companies since no acting law imposes such practices.

\section{B. Evolution of best practices of corporate governance in Morocco}

In order to gauge the evolution of best practices of corporate governance in Morocco, we refer to the ten best practices depicted in the IMA[4] namely: 1/ adoption of the national code of corporate governance, 2existence of a governance charter, 3/- separation between the functions of the Chairman and CEO, 4/- Independence of the board of directors, 5/ existence of specialized committees, 6/- assessment of the governance committee 7/- assessment of senior management, 8/ disclosure of executives' compensation,9/ existence of incitation/ stock option schemes and 10/ disclosing information about the best practices of corporate governance in the annual reports.

\section{Adoption of the national code of corporate governance (CNGE)}

According to the IMA survey [4], more than half of the companies reported referring to the national code of corporate governance. While in our study, we found that just one-third of our sample complies with this code.

This difference can be attributed to the difference of the panel questioned as well as the amalgamation between complying (full conformity to all provision) and referring (partial conformity.)

Thus, it is fair to conclude that equity listed companies have not improve their practices in terms of compliance to the CNGE[15].

\section{Existence of a Corporate Governance Charter}

According to the IMA report, half of their surveyed sample has a code of good conduct or a charter of corporate governance. Our study reveals an improvement in terms of this practice attributed mostly to the financial sector which is abided to comply with the Circular BAM 4 / W / 2014 issued by the Central Bank of Morocco provisioning internal control and governance measures of credit institutions.

\section{Separation between the functions of the Chairman and the CEO}

It should be noted that in Morocco the choice of mode of governance is left to the discretion of each company.

The one tiered mode remains predominant by the majority of companies surveyed in both studies (only 5 out 20 enterprises adoptthe dual mode).

According to our respondents, Moroccan companies are reluctant to separate between the management and control functions which impede the development process of corporate governance in Morocco.

\section{Independence of the board of directors}

Our study depicts an amalgamation of understanding between the independence requirements as it is recommended by the international norms (ROSC and ISS) and the attribute of "non-executive" of the board members required by the National Code of Corporate Governance.

According to the IMA survey, the non-executive directors represent on average more than two-thirds of the board members.

Our study reveals a slight improvement during the past five years contributed by the compliance of the financial sector to the new provisions of BAM circular.We found that less than half of our panel (8 enterprises out of 20) has independent members in their board. The proportion of independent members does not exceed, on average, half of the board of their board.

\section{Existence of specialized committees}

Based upon the acting code and the AMMC circular, it is up to the discretion of the board of director to set and determine the structure of these committees.

In other words, companies might either appoint members or can set up distinct structure for governance, audit and nomination committees.

The IMA survey indicates that two-thirds of companies have specialized committees. We noted an improvement (16 out of 20 enterprises) in this practice attributed to the new circular of the Moroccan Central Bank (BAM) which requires from credit institutions to set up specialized committees namely: the Audit, nomination and governance committees.

\section{Assessment of the board of director}

The results of the IMA survey confirm that half of the companies surveyed have the work of their board of directors been assessed. According to our study, no improvement was observed in this practice as we observed the same results.

\section{Assessment of executives}

According to the IMA survey, more than half of the surveyed firms confirm evaluating the performance of their senior management through key performance indicators (KPI).

We have observed, in our study of 2017, a solid improvement in this practice. The majority of our panel states that they are conducting an annual appraisal of their executives. 
8. Disclosure of Executive Compensation Information Amid the regulatory framework in Morocco requiring compensation of senior management to be approved by shareholders, disclosing the compensation remains restrained to a very limited number of companies. This trend has not changed since the last report published by the IMA. The respondents in our study justify this fact by the sensitivity of the subject.

\section{Existence of an incentive/stock option plan}

The results obtained from our study converge with the findings of the IMA survey in 2012. Only half of our panel confirms having a profit-sharing/ stock option plans.

We noticed no significant improvement in that practice. Furthermore, only Financial and Real Estate and Construction sectors have stock option schemes for their executives. Interestingly, no company confirms disclosing the stock option plans in their annual reports.

\section{Reporting in the annual reports}

The results obtained in our study converge with the findings of the IMA survey in 2012. More than half of our respondents confirm communicating information about their best practices of corporate governance in the annual reports.

\section{v. CONCLUSION}

To sum up, the evolution of best practices of corporate governance in Morocco remains restricted and even stagnant despite several initiatives taken by the market authorities to mention the latest the circular of BAM 4 / $\mathrm{W} / 2014$.

We have raised a salient fact from this study. The implementation of best practices of corporate governance, with the exception of the financial sector, has not yet reached the regulatory stage and the code is still adopted on the basis of voluntary and non-binding membership.

Moreover, the outcomes of our research reveal that the financial and the real estate and construction sectors are the most conforming to the best practices of corporate governance. This fact is explained by the structure of the ownership which is predominantly institutional (local institutional investors or international groups).

On a global outlook, limits are as of today still persisting on what a code and even a "hard law" can achieve: cohesive regulatory frameworks have proven their limits in more than one advanced and market-oriented economy. Emphasis perhaps should be drawn to more innovative venues to enforce the corporate governance codes which could be a future development for this existing article.
VI.

LIMITATIONS AND CONSTRAINTS OF THIS STUDY

In this study, we used rigorous data collection and analysis methods to promote the validity of the results. However, the results presented in this study were obtained from voluntary responses of respondents, which are discretionary to their judgments, perceptions, and the practices applied within their respective companies.

Our research was marked by a number of constraints such as the difficulty in establishing direct access with respondents, the limited size of our sample, the confidentiality and sensitivity of certain information and the time constraint.

As a result, we took recourse of complementary sources of information such as the annual reports of companies and the laws and circulars in force.

\section{ACKNWOLDGEMENT}

We would like to extend sincere thanks to all companies' executives who gave up their time to take part in this research and for transcribing the interviews.

\section{REFERENCES}

[1] Terchoune, M. andBouchikhi, S. (2015) Convergence vers des pratiques de bonne gouvernance: constats théoriques et empiriques cas des sociétés marocaines cotées. European Scientific Journal. 28 (11), 352-358.

[2] Bloomberg. (2015) Emerging Markets report: Outlook on Corporate Governance.

[3] Banque Mondiale. (2010) Rapport de la Banque Mondiale : Evaluation par Pays du Gouvernement d'Entreprise. Royaume du Maroc (ROSC).

[4] IMA. (2012) L'enquête réalisée par l'Institut Marocain des Administrateurs concernant les pratiques de gouvernance ges sociétés cotées.

[5] Charreaux, G. (2011) Gouvernance des entreprises : nouvelles perspectives. Paris :Economica.

[6] Vo, D. and Phan, T. (2013) corporate governance and firm performance: empirical evidence from vietnam. Economic Regulation Authority.G32-G34, 2013.

[7] Adekunle, S.A AND Aghedo E.M.( 2014) Corporate governance and financial performance of selected quoted companies in Nigeria, European Journalof Business and Management. VOL.6, NO.9.

[8] Torea, N. et al.(2016) Board of director's effectiveness and the stakeholder perspective of corporate governance: do effective boards promote the interests of shareholders and stakeholders? BRQ Business Research Quarterly 19 (4), 246-260. 
[9] Chen, E.T. et Nowland, J. ( 2010) optimal board monitoring in family owned companies: evidence from Asia. Corp. Govern.: int. rev. 18 (1), 3-17.

[10]Love, I. (2011) Corporate governance and performance around the world: what we know and what we don't know. World Bank Research Observer. 261 42-70, 2011.

[11] La Porta, R. et al. (1998) Law and Finance. Journal of Political Economy, 106, pp. 1113-1150.

[12] Affes, H. (2011) Indirect effect of leaders incentive system type on financial performance through the level of innovation. Journal of Research in International Business and Management, Volume $1 \mathrm{~N}^{\circ} 4$.

[13] Aggarwal, P.(2013) Impact of corporate governance on corporate financial performance. IOSR Journal of Business and Management.Volume 13, Issue 3.

[14]CDVM. (2010) Circulaire du CDVM n ${ }^{\circ} 05 / 10$ relative au devoir de vigilance et de veille interne.

[15] Code Marocain de Bonnes Pratiques De Gouvernance. (2008-2012). 